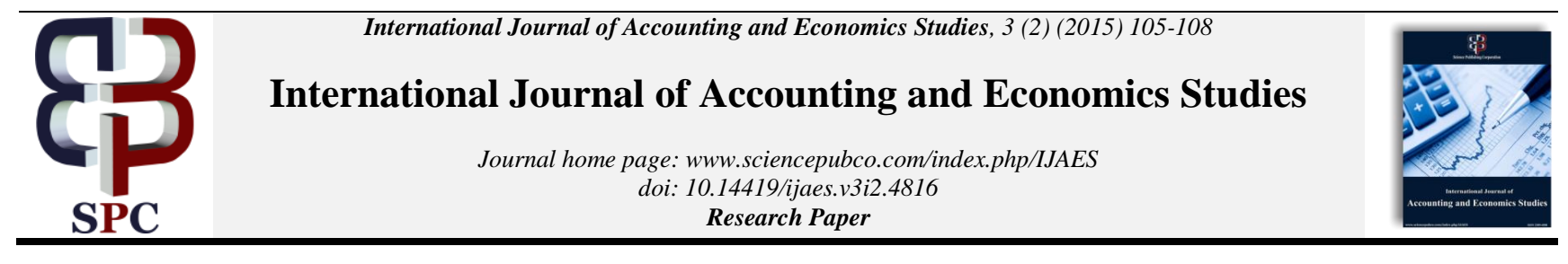

\title{
Financial performance of investment funds as members of Tehran stock exchange
}

\author{
Marzieh Jamadar \\ Graduate student of the Islamic Azad University, Olom Tahghighat Branch, Tehran \\ E-mail: jamdar.marzieh@gmail.com
}

\begin{abstract}
In this research, the financial performance of investment funds as members of Tehran Stock Exchange was measured based on the Modern Portfolio Theory (MPT) measures including Sharpe's, Jensen's, Treynor's and Modigliani's measures. The performance rating of investments was also compared based on the above measures and the relation of any fund's rank with the related measures was examined. Overall, 32 mutual funds were evaluated during 2011-12. The results showed that the net growth percentage of any investment unit's asset value is directly and strongly related to the growth percentage of Sharpe's, Jensen's and Modigliani's measures, but the net growth percentage of any investment unit's asset value is weakly and inversely related to Treynor's measure. The funds' ranks were not also the same based on the abovementioned measures, but there is only a significant relationship between their ranks.
\end{abstract}

Keywords: Mutual Fund; Sharpe's Measure; Treynor's Measure; Jensen's Measure; Modigliani's Measure.

\section{Introduction}

Investment is one of the primary needs for the transition from an undeveloped economy to a developed economy. Undoubtedly, the attention of those interested in investment must be attracted to direct their capitals (Etemadi, 2009). One safe and profitable way of investment is to buy and sell securities. The best way to invest in securities is to have a diverse portfolio that decreases the risk and increases the return. Since this type of investment needs specialized knowledge and a large amount of cash, it can be helpful for investors to use mutual funds that are one of active financial institutions in the securities market.

Mutual funds attract the investors through the advantages of diversification, professional management, liquidity and economies of scale (Soleimani Amiri\&Abed, 2013). The activity of the mutual funds has started recently in the financial market of Iran. Equity mutual funds started their activity in 2008. Despite their short life, mutual funds have grown remarkably in terms of the number and diversity and are at the center of attention (Allameh Haeri\&Hosseini, 2012). According to the unique role of these funds in allocating financial resources in the capital market optimally, the performance evaluation of these financial brokers can provide valuable information to investors. So in this research, it is tried to examine the investment funds' performance based on the MPT measures.

\section{Theoretical framework}

The relationship between risk and return is one of the most wellknown concepts in investment literature, and it is always desirable to obtain the maximum return with a minimum risk. The basis of modern portfolio theory was described by Harry Markowitz and based on the relation between return and risk. In this theory, risk is defined as the deviation from the average return. This research examines the performance of the investment funds in Tehran Stock Exchange based on the MPT measures, including Sharpe's, Jensen's, Treynor's and Modigliani's measures, and the relation between their ranks. In the following, variables of the research as defined:

Net Asset Value (NAV) is, in fact, the value of the fund's total investment divided by the number of its shares that is calculated at the end of any trading day according to the changes in the stock price, securities and the resulting cash profits (stock exchange organization, 2010).

Sharpe index is one of the most important measures to evaluate mutual funds' performance that is adjusted by risk. This index states the excess return obtained by the fund compared with the return on a risk-free asset. In this index, the return on a risk-free asset is noted to determine whether the excess risk due to holding a risky asset is properly compensated for an investor or not. The higher the index is, the more desirable it is, because more riskadjusted return will be obtained.

Like Sharpe's index, Treynor ratio is also a measure of performance evaluation that adjusts the excess return compared to the systematic risk. The difference between Sharpe's index and Treynor ratio is that instead of using the total risk, the systematic risk is used to interpret the return's fluctuations. This ratio, in fact, states that how much adjusted return will be provided to the investor for any unit of the systematic risk.

Jensen's Alpha is also used for performance evaluation of the country's mutual funds. This is also known as Jensen's performance measure.

According to the measure, the return on equity is a linear function of the risk free return and the risk premium during a period. The alpha expresses the excess return compared to the expected return (the return that is expected to be obtained according to the risk incurred). 
A positive alpha shows a better return performance compared to the expected return performance. However, a negative alpha means that the equity performance is lower than the expected return performance. Unlike Sharpe index, Jensen alpha does not use diversity for performance evaluation and only uses the systematic risk. In fact, it notes the effect of the portfolio management to predict the stock price successfully in future (Kordbacheh, 2012). Modigliani ratio uses the standard deviation as a risk measure. Therefore, like Sharpe's index, it is based on Capital Market Line (CML). This measure determines the return if the portfolio has a similar degree of the total risk of the market portfolio (Raei, 2010) It is obtained by the difference between the adjusted portfolio and the index return (market index). Like Sharpe index, this measure takes the total variability to the risk into account, but the riskadjusted portfolio is noted here. This measure was presented by Franco Modigliani and Lieh Modigliani in the risk-adjusted performance article in 1997 in Portfolio Management Review (Vakilifard, 2011).

\section{History of the research}

Safari (2002) examined the performance of the investment companies active in Tehran Stock Exchange based on Sharpe's and Treynor's measures. He concluded that increasing the number of shares in the portfolio, the nonsystematic risk can be decreased and if portfolios are completely diverse, performance ratings based on Sharpe's and Treynor's measures will be close to each other.

Safarpour and Sheikh (2007) examined the performance of the investment companies based on the exchange portfolio and monthly return on equity. The research measured the effect of the in vestment period on the companies' performance. The companies' performance was measured using Sharpe's, Jensen's and Treynor's measures and the results indicated that the performance of the companies with a long-term and short-term investment period is the same. The results also showed that the companies using cash return index and price have weaker performance than the stock exchange, and their performance is similar to the stock exchange based on the 50 active company index.

Abdeh Tabrizi and Sharifian (2008) examined the effect of the undesirable risk on the risk-adjusted performance of the investment companies accepted in Tehran Stock Exchange. The researchers described the existing differences in the performance evaluation measures based on modern and postmodern portfolio theories. In this research, the relation between the companies ratings based on Sharpe's measure and the desirable potential ratio was examined, and it was concluded that the two ratios are related to each other, and it is due to the negative skewness in the return distribution. So it was more reasonable to use the desirable potential ratio.

In the studies conducted on the equity investment funds, Saeidi and Moghadasian (2010) evaluated the funds' performance in terms of the risk-adjusted return using Sharpe's, Treynor's and Jensen's measures and between adjusted return on Sortino ANOVA. According to the results of analysis, there is no significant difference based on the market return beta adjusted -risk funds.

In a research on 14 funds during 2008-2009, Roushangarzadeh and Rezaei (2011) concluded that ratings are not similar based on Modigliani's and Treynor's measure and information ratios, but there is only a significant relationship between them. The results also showed that the trading activity ratio of funds is significantly related to their performance.

Using nonparametric test, Ahmadi (2011) examined the relationship between the ranks of Sharpe's index, Sortino ratio, traditional beta and undesirable beta and the results of the hypotheses' test showed that the ranks are significantly related to each other and the hypothesis about the equality of the ranks was rejected.

In a study conducted in Tehran Stock Exchange, Dindar (2012) concluded that the net asset value is strongly related to the stock price of the companies accepted in the stock exchange. The re- search was conducted for a three-year period in Tehran Stock Exchange.

Using $M^{2}$, Treynor ratio and Sortino ratio, Allameh Haeri and Hosseini (2012) compared the performance of the investment companies and funds. The results showed that on average, there is no significant relationship between the performance of the investment companies and equity, mutual funds and the market performance, and there is also no significant relationship between the performance of the investment companies and the equity mutual funds.

Soleimani Amiri and Abed (2013) found that the investment funds' ratings based on modern and postmodern portfolio theories are significantly related to each other. They also suggest using postmodern portfolio theory measures to evaluate the performance of the mutual funds.

Redman (2000) concluded about the investment funds based on Sharpe, Treynor and Jensen models that the investment funds' ratings based on Sharpe, Treynor and Jensen models are significantly related to each other.

Gullet (2000) studied 7 portfolios using Sharpe index, Treynor ratio and Jensen alpha for two periods of time including 1990-94 and 1985-89. The ratings from two Sharpe's and Treynor's measures were identical for 4 portfolios. This shows that the return obtained by the total risk is equal to that obtained by systematic risk and therefore, the total risk is close to the systematic risk. Lien (2007) examined the relation between ratings of Sharpe's, Treynor's and Sortino's measures. In his research, he addressed the agency issue and stated that since the investment funds are financial institutions that buy and sell and form portfolios through investors and their savings, they play a clear unique role of agency and several different measures must be used to evaluate their performance. He concluded that ratings based on the three measures are not similar.

Chen et al. (2007) presented a new index to measure the investment funds' performance that is known as the efficiency ratio. This ratio uses the portfolio's minimum global deviation as the basis for comparison.

Hubner (2007) presents some empirical evidence about performance measures' evaluation. The results of his research confirm the superiority of Treynor generalized ratio as an optimal measure to evaluate the funds' performance compared to Sharpe index.

Swinkels et al. (2009) evaluated the performance of the mutual funds active in Poland's market empirically. Their research included three classes of the investment funds, i.e. equity funds, balanced funds and bond funds. The results of the research indicated that there is a positive but non-significant relationship between manager selectivity and market timing skill for any class.

Altay (2011) compared the performance of 60 mutual funds in Denmark's financial market and 65 mutual funds in Turkey and analyzed their risk. Using the growth percentage of Sharpe's index, Treynor ratio and Jensen alpha with the assumption of a normal distribution of data, and also using the adjusted Sharpe index with the assumption of a non-normal distribution of data, he found that Turkish mutual funds performed better than Danish mutual funds in most performance and risk models.

Dewi and Ferdian (2012) examined the performance of 14 active Islamic mutual funds in Malaysia and 10 active Islamic mutual funds in Indonesia using Treynor ratio, Sharpe's index, and Jensen alpha and spiral sequence technique. The empirical results obtained showed that Indonesian Islamic mutual funds performed better than Malaysian funds in the chosen period, although Malaysian funds were better and more different from Indonesian funds in terms of Sharpe's index. The results of the spiral sequence analysis also showed a continuously increasing return of the Islamic mutual funds in both countries in contrast to the global economic recession. 


\section{Hypotheses}

H1: The net growth percent of any investment unit's asset value is significantly related to the growth percent of Sharpe index.

$\mathrm{H} 2$ : The net growth percent of any investment unit's asset value is significantly related to the growth percent of Jensen's measure.

H3: The net growth percent of any investment unit's asset value is significantly related to the growth percent of Treynor ratio.

H4: The net growth percent of any investment unit's asset value is significantly related to the growth percent of Modigliani ratio.

H5: The funds' performance ranks are not similar based on Sharpe's, Jensen's, Treynor's and Modigliani's measures.

H6: There is a significant relationship between any fund's rank and the related measure used.

\section{Methodology}

The purpose of the study of the relation between two variables not only entails techniques to define and measure the variables being studied, but it also entails determining statistical methods to describe the nature of the relations between variables. According to the features of the variables studied, the most popular measure used for the correlation analysis in such conditions is Pearson product-moment correlation coefficient. Friedman test is used for rating. It is used to analyze two-way ANOVA (for nonparametric data) and also to compare the average rating of different groups. Kruskal-Wallis test is also used to compare the means of more than 2 rank (or distance) samples. In this test, hypotheses have no direction. In other words, it only shows the difference and doesn't show the larger or smaller direction of the groups' mean.

Data of the investment funds and Tehran stock exchange market indices were drawn from the investment funds website and the center of financial data processing in Iran and Tehran stock exchange website was used to get the required measures to do the research and examine the investment funds' performance based on the measures' growth percent.

\section{Population and sample}

The time interval of the research is two years from 2011 to 2012 The population includes all funds accepted in the Stock Exchange Organization that were active at least for one year in the period. According to the conditions of the research, 32 funds had the required conditions and all of them were examined as the sample of the research.

\section{Analysis of the hypotheses}

\subsection{H1 test}

Table 1: H1 Test

\begin{tabular}{lcll}
\multicolumn{4}{c}{ Table 1: H1 Test } \\
\hline & $\begin{array}{l}\text { Number } \\
\text { of paired } \\
\text { samples }\end{array}$ & $\begin{array}{l}\text { Correlation } \\
\text { coefficient }\end{array}$ & $\begin{array}{l}\text { Significance } \\
\text { level }\end{array}$ \\
\hline $\begin{array}{l}\text { The net growth percent of } \\
\text { any investment unit's asset } \\
\text { value is significantly relat- } \\
\text { ed to the growth percent of }\end{array}$ & 768 & $82.4 \%$ & 0.0001 \\
Sharpe index. & & & \\
\hline
\end{tabular}

*The significance level is assumed to be 0.05 .

The results show that the coefficient of the correlation between the variables " the net growth percent of any investment unit's asset value" and "the growth percent of Sharpe index" is $82.4 \%$ at the significance level 0.0001 and at the level of confidence $95 \%$ (and even $99 \%$ ). In other words, the net growth percent of any investment unit's asset value is significantly, directly and strongly related to the growth percent of Sharpe index.

\subsection{H2 test}

Table 2: H2 Test

\begin{tabular}{llll}
\hline Hypothesis & $\begin{array}{l}\text { Number } \\
\text { of paired } \\
\text { samples }\end{array}$ & $\begin{array}{l}\text { Correlation } \\
\text { coefficient }\end{array}$ & $\begin{array}{l}\text { Significance } \\
\text { level }\end{array}$ \\
\hline $\begin{array}{l}\text { The net growth percent of } \\
\text { any investment unit's asset } \\
\text { value is significantly relat- } \\
\text { ed to the growth percent of } \\
\text { Jensen's measure. }\end{array}$ & 768 & 0.936 & 0.0001 \\
\hline
\end{tabular}

According to the above data, the coefficient of the correlation between the variables "the net growth percent of any investment unit's asset value" and "the growth percent of Jensen's measure" is $93.6 \%$ at the level of confidence $95 \%$ (and even 99\%). In other words, the net growth percent of any investment unit's asset value is significantly related to the growth percent of Jensen's measure. This is a direct relation and a strong correlation.

\subsection{H3 test}

Table 3: H3 Test

\begin{tabular}{llll}
\hline Hypothesis & $\begin{array}{l}\text { Number } \\
\text { of paired } \\
\text { samples }\end{array}$ & $\begin{array}{l}\text { Correlation } \\
\text { coefficient }\end{array}$ & $\begin{array}{l}\text { Significance } \\
\text { level }\end{array}$ \\
\hline $\begin{array}{l}\text { The net growth percent of } \\
\text { any investment unit's asset } \\
\text { value is significantly relat- } \\
\text { ed to the growth percent of } \\
\text { Treynor ratio. }\end{array}$ & 768 & -0.077 & 0.033 \\
\hline
\end{tabular}

The significance level 0.033 shows that the coefficient of the correlation between the variables "the net growth percent of any investment unit's asset value" and "the growth percent of Treynor ratio" is $-7.7 \%$ and the hypothesis of the relation between the two variables is rejected at the level of confidence 95 . Due to the negative correlation coefficient, there is an inverse relation between the variables, but because the correlation coefficient is low, the relation is weak and negligible.

\subsection{H4 test}

Table 4: H4 Test

\begin{tabular}{llll}
\hline & $\begin{array}{l}\text { Number } \\
\text { of paired } \\
\text { samples }\end{array}$ & $\begin{array}{l}\text { Correlation } \\
\text { coefficient }\end{array}$ & $\begin{array}{l}\text { Significance } \\
\text { level }\end{array}$ \\
\hline $\begin{array}{l}\text { The net growth percent of } \\
\text { any investment unit's asset } \\
\text { value is significantly relat- } \\
\text { ed to the growth percent of } \\
\text { Modigliani ratio. }\end{array}$ & 768 & 0.596 & 0.0001 \\
\hline
\end{tabular}

The results of Pearson test show that the coefficient of the correlation between the variables "the net growth percent of any investment unit's asset value" and "the growth percent of Modigliani ratio" is $59.6 \%$ at the level of confidence 95\% (and even 99\%). In other words, the net growth percent of any investment unit's asset value is significantly and directly related to the growth percent of Modigliani ratio. It is also a strong correlation.

\subsection{H5 test}

Table 5: H5 Tes

\begin{tabular}{lll}
\hline Hypothesis & Description & Value \\
\hline & $\begin{array}{l}\text { Number of } \\
\text { measures to be } \\
\text { ranked }\end{array}$ & 4 \\
$\begin{array}{l}\text { The investment funds' performance ranks } \\
\text { Tre not similar based on Sharpe's, Jensen's, }\end{array}$ & $\begin{array}{l}\text { Chi-Square } \\
\text { Degree of free- } \\
\text { dom }\end{array}$ & 87.82 \\
& Sig. & 31 \\
& & 0.0001 \\
\hline
\end{tabular}


Friedman test shows that the prioritization of the investment funds is not similar in terms of Sharpe's, Jensen's, Treynor's and Modigliani's measures. It can be claimed that there is a significant relationship between any fund's rank and the related measure evaluated.

\subsection{H6 test}

Table 6: H6 Test

\begin{tabular}{lll}
\hline Hypothesis & Description & Value \\
\hline There is a significant relationship between any & $\begin{array}{l}\text { Chi-Square } \\
\text { Degree of } \\
\text { fund's rank and the related measure used. }\end{array}$ & $\begin{array}{l}\text { freedom } \\
\text { Sig. }\end{array}$ \\
\end{tabular}

The result of Kruskal-Wallis test shows that the rank of the investment funds is not similar in terms of Sharpe's, Jensen's, Treynor's and Modigliani's measures and there is a significant relationship between any fund's rank and the measure used. So the hypothesis of the existence of a significant relationship between any fund's rank and the related measure is supported at the level of confidence $95 \%$ and it can be generalized to the population of the research.

\section{Conclusion}

The statistical results of the hypotheses showed that the net growth percent of any investment unit's asset value is significantly related to the growth percent of Sharpe's, Jensen's and Modigliani's measures. The results of the fifth and sixth hypotheses also showed that the funds' ranks were not the same based on the four measures, but there is only a significant relationship between their ranks, that confirm the results of researches by Safari (2002), Roushangarzadeh (2011), Ahmadi (2011), Redman (2000) and Lien (2007), but are not consistent with those by Gullet (2000).

It seems that using the net asset value of any investment unit, investors can properly evaluate the portfolio management efficiency, in a way that increasing the net asset value of any fund's investment unit, Sharpe index also increases and this shows the portfolio management efficiency and the fund's proper return. Also increasing the net asset value of any fund's investment unit, it can be concluded that its Treynor's, Jensen's and Modigliani's measures will increase and this shows the portfolio management efficiency and the fund's proper return. Using the increase in the net asset value of any investment unit of the investment funds, the investors can properly evaluate the portfolio management efficiency. Due to the increase in the net asset value of any fund's investment unit, the portfolio management efficiency and the fund's proper return will result. In fact, using the increasing daily return of the investment funds, the investors can get a proper return of the funds.

\section{References}

[1] Etemadi H, Mohammadi A, Nazemi Ardakani M (2009) the Relationship between the Proficiency of the Auditor Industry and Profit Quality in the Companies Accepted in Tehran Stock Exchange, Financial Accounting Rev., yr. 1, nos. 1\&2, fall \& winter.

[2] Dindar Farkoushi P (2012), Comparative Study of the Relation between the Net Asset Value and the Stock Price of the Companies Accepted in the Stock Exchange, Economic Policies and Research Journal, no, 63.

[3] Raei R, Talangi A (2004), Advanced Investment Management, Sam Pub., Tehran.

[4] Roushangarzadeh A (2011), Performance of Investment Funds based on Modigliani Model, 3rd Conference of Financing System Development in Iran.

[5] Stock Exchange Organization (2010), Financial Institutions, Guideline of the Securities Market Law, Information and Exchange Service Company Pub., p. 52

[6] Saeidi A, Moghadasian I (2010), Performance Evaluation of Equity Investment Funds in Iran, Stock Exchange Journal, no. 9, yr. 3, pp. 524, Spring.
[7] Soleimani Amiri Gh, Abed A (2013), Performance Evaluation of the Investment Funds in Iran, Empirical Research of Accounting, yr.2, no.8.

[8] Safarpour M, Sheikh M (2007), the Effect of the Investment Period on the Performance of the Investment Companies Accepted in Tehran Stock Exchange, Quarterly Journal of Accounting and Auditing Surveys, no. 50, pp. 99-118.

[9] Safari M (2002), Performance Evaluation of the Investment Companies Active in Tehran Stock Exchange based on Sharpe's and Treynor's Measures, master thesis, Faculty of Management, Tehran University.

[10]Abdeh Tabrizi H, Sharifian R (2007), the Effect of Undesirable Risk in the Performance Evaluation of the Investment Companies Accepted in Tehran Stock Exchange, Financial Research, no. 24, ser. 9.

[11]Allameh Haeri F, Hosseini M (2012), Performance Evaluation and Comparison of the Investment Companies (Accepted in Tehran Stock Exchange) and Equity Mutual Funds, Financial Accounting Scientific \&Research Journal, yr. 4, no.16.

[12]Kordbacheh H (2005), Risk-adjusted Performance Evaluation of $\mathrm{Mu}$ tual Funds in Iran, Financial Research, no. 19.

[13]Momeni, M (2012), Statistical Analysis Using SPSS, Ketab-e-No Pub.

[14]Vakilifard H (2011), Making Decision about Financial Problems, Jangal Pub.

[15]Altay E (2011), The Performance and Risk Analysis of Danish Mutual Funds and Turkish Mutual Funds and Their Comparison, Aarhus School of Business, Arhus University

[16]Dewi MK \& Ferdian IR (2012), Evaluating Performance of Islamic Mutual Funds in Indonesia and Malaysia, Journal of Applied Economics and Business Research (JAEBR), Vol. 2, No. 1, PP. 11-33.

[17]Gullet NS (2000), Evaluating Mutual Funds in Emerging Market: Factors that Matter to Financial Advisors, Vol, 21, pp.122-136.

[18]Hubner G (2007), How Do Performance Measures Perform?" Journal of Portfolio Management; Vol. 33, No. 4; Pp: 64-74. http://dx.doi.org/10.3905/jpm.2007.690607.

[19] Chen WK, Chen YJ and Chen TCh (2007), Using Efficiency Ratio to Measure Fund Performance, Journal of Asset Management, Vol. 8, No.6, Pp: 352-360. http://dx.doi.org/10.1057/palgrave.jam.2250088.

[20]Lien D (2007), A Note on the Relationship between Some Risk Adjusted Performance Measures, Journal of Future Market, Vol 22, No5, pp.483-495. http://dx.doi.org/10.1002/fut.10024.

[21]Redman L A (2000), the performance of mutual funds, Springer.

[22] Swinkels L, Rzezniczak P (2009), Performance Evaluation of Polish Mutual Funds Managers, International Journal of Emerging Markets,

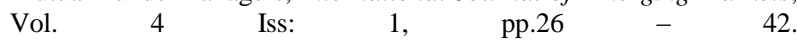
http://dx.doi.org/10.1108/17468800910931652. 